\title{
Brasil - construção e desconstrução do desenvolvimento *
}

\author{
Wilson Cano ${ }^{* *}$
}

\section{Resumo}

O artigo procura sintetizar o movimento geral da economia brasileira, e alguns fatos marcantes, desde 1930 a 2016, que alteraram parcialmente a trajetória do período. O subperíodo de 1930 a 1980, compreende nossa fase áurea de crescimento e industrialização, o de 1980 a hoje - o da desconstrução do desenvolvimento do país.

Na boa tradição da História e da Economia Política, comento outros fatos anteriores muito relevantes, que exerceram efeitos cumulativos subsequentes. Incluo também as principais circunstâncias internacionais que, em cada momento, tiveram forte influência nessas mudanças.

Na terceira parte, centrada no pós-1980, resumo alguns efeitos políticos e sociais sofridos pela sociedade brasileira, que a meu juízo, foram fortemente - mas não exclusivamente - influenciados por aquelas transformações econômicas e institucionais, especialmente pelo Neoliberalismo e pela Globalização no segundo período.

Na parte final relato o aprofundamento da crise atual, e indago sobre o futuro imediato de nosso desenvolvimento.

Palavras-chave: Construção; Desconstrução do Brasil; (Des)industrialização; Crise política; Subdesenvolvimento.

\begin{abstract}
\section{Brazil: the construction and deconstruction of development}

The article with provide an overview of the Brazilian economy between 1930 and 2016 and the most relevant facts during the period, as well as the international circumstances that played a significant role in the changes that took place. During the first period, the golden phase between 1930 and 1980, the country boomed with economic growth and industrialization, whereas the following period (from 1980 until today) is marked by the interruption in the development path. The third part of the article focuses on the post 1980's period, showing how some political and social effects suffered by Brazilians were strongly - but not exclusively - influenced by those changes, both economic and institutional, particularly by neoliberalism and globalization. In the final part I report the deepening current crisis and investigate the immediate future of Brazil's development.
\end{abstract}

Keywords: Construction; Brazilian Deconstruction; Deindustrialization; Political Crisis; Underdevelopment.

JEL 014, O54.

* Artigo recebido em 1 de julho de 2017 e aprovado em 16 de julho de 2017. Agradeço aos colegas professores Cláudio S. Maciel, Fernando Macedo e Humberto N. Miranda, do IE-CEDE, e ao parecerista não identificado desta revista, pelos comentários ao texto.

${ }^{* *}$ Professor Titular aposentado do Centro de Estudos do Desenvolvimento Econômico (Cede) do Instituto de Economia da Universidade Estadual de Campinas (Unicamp. IE), Campinas, SP, Brasil. E-mail: wcano.@unicamp.br. 
Este texto tem por objetivo central fazer uma síntese sobre o movimento geral da economia brasileira, e de alguns de seus principais fatos, desde 1930 a estes dias. Dois períodos são analisados, de 1930 a 1980 e de 1980 até hoje, e a análise não só considera os fatos mais marcantes que alteram pelo menos em parte, a trajetória histórica de cada período, mas também outros, anteriores, muito relevantes, que continuam a exercer efeitos cumulativos em períodos subsequentes. Leva ainda em consideração as principais circunstâncias internacionais que, em cada momento, também exerceram forte influência nessas transformações.

O período de 1930 a 1980, compreende nossa fase áurea de crescimento e industrialização, será tratado no tópico 1 e o de 1980 a hoje - o da desconstrução na parte 2. Na parte 3, centrada no pós-1980, tentarei, resumidamente, apontar alguns efeitos políticos e sociais sofridos pela sociedade brasileira, que a meu juízo, foram fortemente - mas não exclusivamente - influenciados pelas principais transformações econômicas e institucionais ocorridas, principalmente no segundo período.

Na parte 4, resumo o aprofundamento da crise atual, e indago sobre o futuro imediato de nosso desenvolvimento.

\section{A construção: 1930-1980}

\subsection{Principais circunstâncias externas}

A década de 1920 mostrava uma economia mundial que não superara os maiores estragos da Primeira Guerra, com o comercio mundial desintegrado, e com grande volatilidade financeira. Os EUA foram os grandes ganhadores do conflito, em termos militar, econômico e financeiro, já antecipando seu papel de futura potência hegemônica do capitalismo.

Ao mesmo tempo em que as debilitadas nações europeias tentavam se recuperar, os EUA viveram um extraordinário boom industrial, que terminaria no segundo semestre de 1929, convertendo-se na maior depressão que o capitalismo até então vivenciara. A “Crise de 29” estendeu-se, na maioria dos países, até 1937, só diminuindo seus devastadores efeitos, através de políticas anticíclicas do tipo keynesiano, e, principalmente, pela economia de guerra que se instaura já a partir de $1937^{1}$.

Mas o envolvimento na guerra até fins de 1945 e a reconstrução dos principais países envolvidos, se estende até o início da década de 1950. Os grandes vencedores foram, do lado do capitalismo, os EUA e do lado do socialismo, a URSS, que passaram, a partir daí, a exercerem o papel de potências hegemônicas desses sistemas.

(1) Sobre o tema, ver Bleaney (1985), Fano (1979) e Kindleberger (1985). . 
O pós-Segunda Guerra, entretanto, seria paradoxal: geraria grande otimismo, pelo fim do conflito, pela derrota nazifascista, pelo prenúncio do fim do colonialismo e pela ilusão que o american way of life despertou no mundo ocidental. Mas geraria também um enorme temor pela possibilidade de uma Terceira Guerra, agora nuclear, temor de que os EUA usariam não só para assegurar seu papel militar mundial, mas para conter a expansão soviética. Assim nascia a política internacional da Guerra Fria, que afetaria a todos.

Ao mesmo tempo, os esforços e os gastos norte americanos com a reconstrução e a cooperação à Europa e ao Japão proporcionariam uma retomada de crescimento e desenvolvimento ímpar no capitalismo, que foram os Golden Years (1950-1975), período de alto crescimento e de alta industrialização principalmente na Europa Ocidental e no Japão, que incorporaram, em grande medida, o padrão norte americano ${ }^{2}$.

Contudo, se as coisas iam bem daquele lado do planeta, o mesmo não ocorria com os EUA. Ao final do conflito, tinham o duopólio do poder militar e das armas nucleares, o poder da moeda "única", e de suas capacidades financeira, produtiva e tecnológica. Além das grandes transferências de dólares para a Europa e Japão (principalmente via Plano Marshall, ajuda ao Japão e manutenção de bases militares no exterior), também realizaram uma grande extroversão de capital produtivo e financeiro (empresas e bancos dos EUA) principalmente para a Europa. Acrescentese que, com a reconstrução daqueles países, os EUA perdiam parte de seu privilegiado mercado externo, excepcionalmente acrescido durante o conflito e o imediato pós-guerra.

A combinação desses fatos engendrou um processo de enorme saída líquida de dólares, mais que compensando os positivos saldos acumulados durante a guerra, ao mesmo tempo que aqueles países passaram a acumular grandes excedentes de dólares, cada vez mais desvalorizados.

Esse fenômeno foi responsável, em grande medida, pela criação do chamado Euromercado de Dólares, que crescia, à medida que aumentasse o fluxo líquido negativo dos EUA, agravando ainda mais a desvalorização do dólar e aumentando a inflação americana.

Com isso, o sistema financeiro internacional cresceu ainda mais, ampliando também as bases para a especulação, volatilidade e inflação - impulsionada, inclusive, pelos dois choques do petróleo, em 1973 e 1979 -, fazendo crescer as pressões externas, pincipalmente da Alemanha, França e Japão, reclamando da "falta de austeridade" dos EUA, o maior devedor internacional, e reforçando a equivocada ideia de que esse país havia perdido sua hegemonia sobre o capitalismo mundial.

(2) Sobre o tema, ver Teixeira (1983) e Torres Filho (1983). 
A reação americana não se faria esperar por muito tempo: em 1979, logo após a reunião internacional do FMI, os EUA usariam uma medida de política fiscal que só aparentemente era paradoxal: embora fossem os maiores devedores do mundo, elevaram sua taxa de juros, que passaria de $7 \%$ para cerca de $21 \%$ ao longo de $1979-1983 !^{3}$

Mas há que destacar, contudo, que o crescimento virtuoso entre 1950 e 1975 foi acompanhado, na Europa e no Japão, por forte aumento do emprego, dos salários, e pela instauração de políticas de bem-estar social, proporcionando maior ascensão social à classe trabalhadora e à classe média, e perspectivas de um grande futuro pessoal e familiar. Além disso, o progresso econômico, político e social traria também enorme desenvolvimento científico e cultural.

Os anos de ouro terminariam em 1974-75, abrindo caminho para a crise internacional que se estenderia para os países desenvolvidos até 1980, mas que se prolongaria por toda a década aos países subdesenvolvidos e aos socialistas muito endividados.

Mas a humanidade, naquele momento, ainda não se dera conta de que o American Dream há muito havia acabado, e que dias sombrios estavam prestes a chegar.

\subsection{Brasil: circunstâncias internas e principais transformações}

Nosso país, até a Revolução de 1930, era constituído por uma economia mercantil-agrária-exportadora e, naturalmente, livre cambista. Já possuíamos uma indústria leve, embora criada, induzida e subordinada pelo setor exportador, como nos ensinou Furtado. Não contávamos, até então, com um efetivo processo de industrialização.

A “Crise de 29" foi demolidora: enquanto durasse a crise internacional, não haveria lugar para o liberalismo e o livre-câmbio. Sua profundidade e longa duração não permitiria a "volta ao passado " notadamente àqueles poucos países que já dispunham daquela indústria induzida pelas exportações, incipiente, mas que, diante da severa crise, seria capaz de suprir parte da demanda interna ${ }^{4}$.

Embora incipiente, essa economia já fizera brotar a produção de alguns manufaturados e de vários serviços, e uma urbanização que perfazia cerca de $30 \%$ da população. Mas as pré-condições para o desencadeamento da Construção eram insuficientes. Nossa burguesia era eminentemente mercantil e raríssimas as

(3) Sobre o tema, ver Tavares e Melin (1997).

(4) Sobre o tema, ver, para a América Latina, Seers (1962) e para o Brasil, Furtado (1961, cap. 28-32) e Cano (2006). 
lideranças industriais; uma classe política frágil e liberal e um Estado livre-cambista. Poucas vozes opinariam pela necessidade de mudança.

Contudo, algumas alterações haviam se dado no processo de acumulação, criando novos interesses, um pouco divergentes daqueles praticados pela oligarquia rural. Assim, e como na maior parte dos processos de industrialização, as lideranças políticas mais críticas, que pensam na nação e no progresso, desencadearam um processo político revolucionário.

Liderada por Vargas, a Revolução de 1930 foi amplamente vitoriosa. Construímos um novo Estado, necessariamente interventor e desenvolvimentista. Criamos um incipiente sistema de Planejamento e Administração Pública e formamos um novo quadro técnico de funcionários públicos. Retomamos o caráter público do Banco do Brasil, dirigindo o crédito público para os novos objetivos da nação. A Política Econômica passou a ser efetivamente administrada para a industrialização.

Recuperamos o crescimento já em 1933 e atravessamos a tempestade da Grande Depressão e da Segunda Grande Guerra, avançando na industrialização. Com ela, cresceu a urbanização e a classe trabalhadora, para a qual o Estado criou uma legislação protetora.

Terminada a Guerra, as forças liberais depuseram Vargas e tentaram a "volta ao passado", elegendo Dutra. Mas o país já havia andado muito à frente. Apresentara elevadas taxas de crescimento do PIB e da indústria; ampliara a classe trabalhadora; as forças políticas de Vargas haviam crescido; surgiram novas lideranças políticas e industriais; a urbanização e a estrutura econômica avançaram com a implantação da siderurgia, papel e cimento, cristalizando novos interesses dificilmente removíveis. ${ }^{5}$ Para sorte do país, o apelo ao retrocesso durou pouco e o novo governo viu-se impelido a dar uma certa continuidade ao processo. A indústria já adquirira o comando político da acumulação de capital.

Vargas retorna e governaria o país de 1951 a 1954, quando aprofundaria sobremodo suas intenções de industrialização. Avança na formação de quadros (com a famosa Assessoria Econômica da Presidência da República) e, mesmo com um Congresso em grande parte hostil, pôde usar toda sua habilidade política e realizar enorme avanço da estrutura industrial, especialmente na indústria de base ${ }^{6}$.

Para isso, fez o importante Plano de Reaparelhamento Econômico e várias regulamentações, criou grandes empresas estatais, como o BNDE e a Petrobrás. A despeito dos resultados positivos, a situação política foi se tornando mais grave, e para isso certamente a questão da Guerra Fria muito colaborou, com as crescentes

(5) Sobre o tema, ver Cano (2015).

(6) Ver a respeito Cano (2015) e Lima (2013). 
pressões dos EUA contra governos latino americanos nacionalistas e progressistas. Seu suicídio, em agosto de 1954, seguramente adiou, por dez anos, o golpe que a direita daria em 1964.

Após esse impasse político, é eleito Juscelino Kubitschek, também progressista e de grande habilidade política, que, entre 1956 e 1960, através, principalmente de investimentos externos, intensificou o desenvolvimento da estrutura industrial, com a implantação ou expansão da produção de bens de consumo durável (entre os quais veículos) e de produção. Lembremos que a participação da indústria de transformação no PIB, que era de $12,5 \%$ ao final da década de 1920, alcançava $20 \%$ em 1955, saltando para $26 \%$ em 1960! A participação dos bens de consumo não durável, que em 1920 era de $78 \%$ caíra para $45 \%$ em $1960^{7}$.

Isto, além do elevado crescimento econômico, aprofundaria ainda mais o processo de industrialização e de urbanização de 1930 a 1960. A intensidade e velocidade desse processo causou grandes efeitos positivos e negativos. Os positivos, além do crescimento da oferta de bens e serviços, também se refletiam no emprego, nos salários e na ascensão social do trabalhador e da classe média. Acrescente-se que o fenômeno da expansão urbano-industrial também amplifica a conscientização política, o crescimento sindical, a expansão da cultura e da arte; amplifica também a reivindicação maior dessas melhorias.

A urbanização se tornaria explosiva, mostrando claramente o déficit habitacional, de saneamento e de transporte público. No campo, pouco se fez, aumentando o êxodo rural e o crescimento do pleito pela reforma agrária. Os serviços públicos de educação e saúde também mostravam suas insuficiências. A ameaça ou o sentimento de ingerência externa, que poderia paralisar ou pôr em risco a continuidade do processo de crescimento, acirrou também os ânimos nacionalistas. O conjunto de todos esses problemas fez crescer as manifestações sociais, consubstanciadas nas chamadas Reformas de Base (Agrária, Urbana, Tributária, Educação e outras).

A continuidade do crescimento se daria até 1962, e a partir daí se desencadearia uma crise econômica, política e social, culminando no golpe civilmilitar de 1964. A crise econômica se manteve até 1965, quando mudam os parâmetros da política econômica, alterando as bases do crescimento.

Cabe lembrar que vários instrumentos de política econômica estavam muito debilitados, pois o Congresso não concedia ao governo as reformas necessárias. Exemplo maior disso residia na carga fiscal e na estrutura tributária, que se

(7) Ver a respeito Furtado (1988) e Lessa (1975). 
encontrava congelada desde meados da década de 30 , quando a indústria ainda era incipiente.

O lado positivo da ditadura militar foi o de assumir uma postura um pouco mais nacionalista e acentuadamente desenvolvimentista, atuando fortemente na modernização do setor agrário exportador, da infraestrutura, e acelerando a industrialização. As Reformas pleiteadas pela esquerda, foram implantadas pela direita, porém, em sua maior parte, com sentido muito diverso ao daquele pleito ${ }^{8}$.

A estrutura tributária foi modernizada, mantida sua regressividade. A reforma do sistema financeiro atendeu a necessidade de modernização e expansão do crédito (notadamente para o setor agroexportador), e instituiu a correção monetária como mecanismo que tentava preservar os valores reais dos ativos e passivos do sistema, notadamente da dívida pública. Além disso, foram também instituídos vários incentivos fiscais estimulando investimentos e exportações. A reforma trabalhista eliminou a estabilidade do emprego, trocando-a pela instituição do atual FGTS. Com isto, o regime pôde criar um forte fundo financeiro que lastrou a nova política habitacional e de saneamento, com a qual foram construídas cerca de 4 milhões de residências.

Essas reformas além de dar maior base à economia do setor privado, provocaram radical transformação e expansão das finanças públicas, permitindo ao setor público ampliar fortemente seu gasto e principalmente seus investimentos, além de proporcionar o crescimento e expansão das empresas estatais.

Com isso, a taxa de inversão cresceu, chegando a atingir $25 \%$ nos anos médios da década de 1970, o PIB cresceu $7 \%$ e a indústria de transformação, em cerca de $9 \%$, ampliando ainda mais sua participação no PIB, para $31 \%$ em 1980, bem como aumentando o peso dos bens de produção em sua estrutura. As exportações tiveram elevado crescimento e apresentaram expressiva diversificação de sua pauta ${ }^{9}$.

Mas o lado negativo do regime foi também alto. Além da retirada de direitos trabalhistas, a política de reajustes salariais prejudicou os trabalhadores. A intensidade do crescimento -industrial, notadamente- induziu forte expansão da demanda de trabalho mais qualificado, abrindo ainda mais o leque salarial urbano e, com isso, agravando a distribuição de renda no país. $\mathrm{O}$ pecado maior talvez tenha sido o bloqueio feito à reforma agrária, com o que foram mantidas as estruturas rurais mais conservadoras do país.

A elevação dos investimentos públicos foi problemática, pois exigiu elevado financiamento externo (privado e público) enquanto suas metas, em parte irrealistas, pressionaram demais as finanças públicas, restringindo as possibilidades de maior e

(8) Sobre a crise e as reformas, ver Tavares (1972 e 1998a).

(9) Ver a respeito Tavares (1988a). 
melhor atendimento da crescente demanda por educação e saúde. A "solução" deste último problema viria através da forte privatização do ensino e da saúde. Os piores efeitos econômicos foram os do enorme aumento da dívida externa, gerados pelo elevado financiamento internacional.

Além disso, não esqueçamos do largo uso do cerceamento das liberdades civis dos cidadãos, da censura, da tortura e da corrosão da política e da classe política nacional, com sua parte mais conservadora apoiadora do regime, reduzida a massa de manobra, do que, aliás, não se curou. Por último, é preciso também lembrar que até hoje a sociedade está pagando muito caro pela omissão e maus tratos sofridos pelo sistema educacional público, que também não se recuperou.

Já a partir de 1974-75, a crise internacional restringia fortemente o crédito externo aos países subdesenvolvidos, forçando a desaceleração da economia brasileira. A ameaça de desvalorização cambial, que fatalmente quebraria muitas empresas no país, fez com que o Estado assumisse grande parte do endividamento privado, em dólares, o que ampliou o rombo nas contas públicas externas e nas finanças públicas.

O longo período de 1930-1980 também nos trouxe algumas das benesses do desenvolvimento: maiores e melhores empregos, salários, urbanização ${ }^{10}$, e indicadores sociais, insuficientes, todavia, para apagar as sequelas de nosso subdesenvolvimento. Ou seja, para liquidar com nossas endemias rurais e urbanas, nosso analfabetismo, nossa enorme carência de saneamento básico.

A expansão quantitativa do ensino infelizmente foi acompanhada por uma piora qualitativa. A política habitacional foi bastante atuante, mas incapaz de diminuir o déficit habitacional da população de mais baixa renda; as condições urbanas já apontavam também para um difícil quadro bem como as do transporte urbano.

De forma mais otimista, tivemos enorme criatividade cultural, especialmente na música, cinema, teatro e nos esportes, com muitos expoentes que inclusive adquiriram renome internacional.

Passamos a ter melhores perspectivas de futuro: as famílias tinham expectativas de que seus filhos teriam melhor educação e saúde; e que encontrariam melhores empregos; a sociedade, acreditava no fim próximo da ditadura e na restauração da política. Esperávamos, enfim, que a crise passasse e pudéssemos continuar nossa industrialização.

A Construção do desenvolvimento havia sido interrompida, mas como o país ainda crescera a taxas altas, entre 1975 e 1980, eram muito poucos os críticos que se

(10) Em 1980 a população urbana já atingira $67,6 \%$ do total. 
davam conta disso. Menos ainda, que o pior estava à nossa espera, e que o "Sonho" havia acabado ${ }^{11}$.

\section{A desconstrução: (1980-...)}

\subsection{Principais circunstâncias externas}

A desregulamentação do sistema financeiro nos EUA, já vinha desde a década de 1960, aumentando nos setentas, soltando as amarras para o reinado do Império do Dinheiro, estimulado pela inflação e pelos petrodólares no euro mercado de dólares. Nos EUA, famílias e empresas já vinham mudando a estrutura de seus ativos - de reais para financeiros -, crescendo o endividamento de ambas. Os enormes rombos financeiros externos dos EUA eram cobertos principalmente pela Alemanha e Japão, cujos capitais, eram inexoravelmente atraídos pelas elevadas taxas de juros dos EUA. No entanto, os enormes rombos comerciais impulsionaram a retomada do crescimento para a Europa e Japão ao mesmo tempo que barateavam parte do Consumo e do Investimento internos dos EUA, diminuindo as pressões salariais e os custos de inversão.

Assim, a financeirização da economia se estendia, basicamente pelos EUA, Europa e Japão, promovendo profundas inovações nas instituições e mercados financeiros, e fazendo surgir expressivos movimentos especulativos em vários países. Entre 1980 e 1995, os ativos financeiros mundiais totais cresceram à taxa média anual de $15 \%$, quatro vezes maior que a do PIB! Dessa forma, o dólar se valorizava e a política fiscal americana ditava as regras à economia mundial, restaurando a hegemonia supostamente perdida no final do período anterior pelos $\mathrm{EUA}^{12}$.

Em 1985, no Acordo de Plaza, os EUA praticamente obrigaram Europa e Japão a aceitar, "gradativamente", a desvalorização do dólar, que provocaria uma desaceleração do crescimento daquelas regiões, valorizando suas moedas, encarecendo suas exportações e barateando suas importações. Após anunciar em 1983 seu programa de defesa "Star Wars", praticamente precipitaria a crise da URSS, que não teria condições financeiras -principalmente orçamentárias- para competir com aquele programa. No mesmo ano a URSS lançava, precipitadamente, a perestroika e a glasnost, iniciando sua desintegração, que culminaria em 1989 com a queda do Muro de Berlim e em 1991 com a dissolução da URSS - extinguindo a bipolaridade mundial - e do Comecon.

Esses estragos possibilitaram aos EUA, o reenquadramento político, econômico, tecnológico e militar do mundo, criando plenas condições para a

(11) Ver a respeito: Cano (2000), Cardoso de Mello e Belluzo (1982), Furtado (1992) e Lessa (1998).

(12) Ver a respeito Belluzzo e Tavares (1980) 
imposição do Neoliberalismo e da Globalização, que já vinham sendo ensaiados desde os setentas ${ }^{13}$. Os estragos também se estenderiam aos países subdesenvolvidos e alguns socialistas, que, pela dimensão de suas dívidas externas, quebraram com a alta dos juros. Estes sofreriam, ainda, o duro, costumeiro e ineficaz remédio dos ajustes ortodoxos sobre suas economias, a feitio do FMI e do BIRD.

O longo período de crescimento chegara ao fim, desacelerando fortemente a taxa de lucro, a de inversão e o " estoque disponível” de novas tecnologias. Por outro lado, o período áureo de crescimento havia proporcionado importantes ganhos (de direitos e pecuniários) à classe trabalhadora, através de suas lutas ou pelo Estado do Bem-Estar Social, que além disso, e por conta das necessidades objetivas da Reconstrução e do Desenvolvimento, coordenara as principais decisões de investir, além da forte regulação que exercia sobre a economia e a sociedade.

É comum, na história do capitalismo, vermos que em períodos de crise profunda, os capitalistas se voltam contra a classe trabalhadora - para lhe reduzir a fatia do bolo -, contra as benesses "populistas" do Estado, assim como contra a “excessiva intervenção" nos negócios, reivindicando a "volta ao mercado".

Essa grita se inicia ainda no começo da década de 1970 nos EUA e na Inglaterra e teve como um dos lances mais pitorescos, o início da reaproximação com a China, em 1971. A inflação e desaceleração dos EUA, vis-à-vis a expansão da Europa e do Japão retardou, até o fím da década, a guinada neoliberal, que só poderia se iniciar a partir da retomada da hegemonia americana, em 1979-1980 após o magistral jogo de xadrez internacional representado pela brutal elevação da taxa de juros reais nos EUA.

Duas eram as questões centrais a enfrentar:

i) a reestruturação produtiva ${ }^{14}$ : visando a retomada do crescimento, via profunda reestruturação produtiva, econômica e financeira dos sistemas produtivos nacionais;

Este objetivo tinha em mira a reorganização e modernização das grandes empresas - algumas delas se converteriam nas futuras ETs - para prepara-las às novas formas exigidas pela concorrência internacional, reduzir custos e elevar a produtividade.

Isso envolveu, de um lado, a criação ou o aprimoramento de layouts, fluxogramas, novos processos produtivos, minimização de estoques de produtos e insumos, novos materiais, nova logística e novos procedimentos comerciais. De outro, as questões mais cruciais:

(13) Ver a respeito Tavares e Melin (1997).

(14) Ver a respeito Fajnzylber (1983). 
a) automatização da produção: transformando processos e produtos da II RI e desencadeando o que se convencionou chamar de III RI, a revolução da microeletrônica, da informática e da automatização, reduzindo a necessidade de trabalho vivo e ouros custos de produção;

b) a da concentração e centralização de capitais, indispensável para a concretização das tarefas acima e poder enfrentar a concorrência internacional. Nunca se viu nada semelhante ao elevado número de fusões e aquisições e do capital nelas envolvido. Foi através desse processo que as grandes empresas mundiais venderam entre si, linhas de produção nas quais uma empresa A tinha menor poder de mercado mas que, para outra, B, representava uma excelente aquisição. Com isto, não concentrou e centralizou apenas o capital envolvido, mas principalmente a produção de tais bens, e o acervo privado das novas tecnologias, desmistificando, com isso a balela teórica da tecnologia como "bem público".

Obviamente, a reestruturação se socorreu de várias fontes, como estas operações ajudaram a expandir ainda mais o sistema financeiro internacional, alargando sobremodo o mercado de títulos e o capital fictício.

A despeito da crítica à intervenção do Estado, esses procedimentos contaram com o franco apoio dos Estados Nacionais de origem dessas empresas, através da formulação de políticas industriais, de financiamento público e de incentivos fiscais.

O grande uso de IDE para essa reestruturação tornou-se necessário, pois a internacionalização privada se confrontava com a intensificação das ações das maiores instituições de integração regional como o MCE (em 1986) e do NAFTA, integrando os EUA e o Canadá em 1988, e o México em 1994, onde aliás, os EUA já haviam implantado um conjunto importante de indústrias maquiladoras.

Esse movimento integracionista objetivava, naturalmente, proteção aos seus mercados regionais, obtenção de economias externas e de escala, além de trabalho barato, no caso das maquiladoras. Os dados do registro desses fluxos mostram centenas de bilhões de dólares dos EUA para a Europa, e vice-versa, poucos fluxos em direção ao Japão, e grandes fluxos deste para os EUA e Europa.

Acrescente-se que no mesmo período, o Japão fazia grandes investimentos na Ásia - principalmente na Coréia do Sul -, criando um processo de integração de mercados, tecnológico, produtivo e financeiro com os principais países do Sudeste Asiático. Nos noventas também se inicia um processo de grandes investimentos de capital na China, na maioria asiáticos, mas também dos EUA e Europa. Assim era consolidada essa internacionalização de capital nas décadas de 1980 e de 1990.

A reestruturação no hemisfério norte ocorreu praticamente em todos os países industrializados, basicamente, durante a década de 1980, mas continuou nos anos seguintes, à medida em que a renovação tecnológica prosseguisse, dando novos 
saltos. Passado o período inicial, havia a necessidade do capitalismo em reestruturar suas plantas também no mundo subdesenvolvido.

Contudo, havia que remover três obstáculos na maior parte dos países subdesenvolvidos: a enorme dívida externa acumulada por esses países, e multiplicada pelos juros reais a partir de 1979-1980; a alta inflação que irrompe a partir da crise da dívida e o fato de que, para isso, o capital externo teria que negociar a adoção das "reformas necessárias" com os governos desses países.

Mas isto não seria problema maior, haja vista o apoio e assessoria dada pelo FMI e BIRD a esses países, e ainda, pelo fato de que a maioria dos governos latino americanos que assumem nos períodos de "redemocratização" já haviam sido "depurados" politicamente, dado os maléficos efeitos da crise e da inflação. A receita foi facilmente vendida: implantar as reformas, sem o que, não haveria reestruturação, retomada do crescimento, e, nem muito menos, o acesso à globalização.

\section{ii) o Neoliberalismo e a Globalização}

As medidas preconizadas pelo Consenso de Washington praticamente cobrem o conjunto das reformas de caráter neoliberal sugeridas formalmente em 1989 ${ }^{15}$. A elas deve-se juntar o Acordo de Basiléia (a partir de1986), com recomendações e normas regulatórias sobre o capital dos bancos (públicos e privados) e de seus riscos de crédito. Elas foram implantadas, na América Latina, a partir do final da década de $1980^{16}$. Esse conjunto de reformas pode assim ser resumido:

\section{a) reforma financeira}

Propunha a desregulamentação sobre a movimentação internacional do capital, sendo que a abertura plena, exigia a abertura da conta de capital do Balanço de Pagamentos. China, Índia e Rússia foram os únicos países que se recusaram a abrir essa conta ${ }^{17}$.

Reforma interna: para viabilizar a abertura financeira internacional era necessário também reformar os sistemas financeiros nacionais, além de cumprir com os Acordos de Basiléia. A reforma nacional deveria conter ainda, a implantação do sistema de metas de inflação, a independência do Banco Central, adesão ao Acordo

(15) Ver a respeito World Bank (2005); para uma visão crítica: Chang (2004), e para América Latina e Brasil (Cano (2000).

(16) Houve tentativas "precoces" (e fracassadas) durante os regimes militares de alguns países, como os do Chile Uruguai e Argentina, ainda nos anos setentas Cf. Cano (2000).

(17) Sobre as linhas gerais da evolução recente desses países, ver: China: Jinping (2014), Medeiros (2005) e Singh (1993); Índia: Nassif (2006); Rússia: Paulino (2010). 
de Basiléia. Além de tornar o mercado de câmbio e o do dinheiro, os mais livres possível.

\section{b) abertura comercial}

Adesão ao livre comércio, reforçada em 1994 com o fim da Rodada Uruguai e a constituição da OMC. Para isso era necessário o máximo de rebaixamento de tarifas e eliminação de outras regras protecionistas ou restritivas ao comércio internacional.

\section{c) reformas do Estado}

Sugeria reformas administrativas, fechamento de órgãos, dispensa de funcionários, abandono de várias funções e intervenções públicas, como sistemas de planejamento, de controle de investimentos privados e restrições sobre algumas políticas sociais. Propugnava o equilíbrio fiscal e monetário.

Privatização de ativos públicos: indicada como meio de obter recursos para "pagar" a dívida pública e acabar com os altos custos e ineficiências da produção pública de bens e serviços. É a busca, enfim, do Estado Mínimo.

Reforma e Privatização da Previdência Social (pública e privada): como meio de também enxugar o Estado e o gasto social, aumentando as contribuições dos trabalhadores, eliminando direitos e alongando as datas para obtenção dos benefícios. Ao mesmo tempo, a lógica da medida era também criar mercados privados para esse serviço social, para o sistema financeiro.

\section{d) Reformas da legislação sobre Contratos de Trabalho.}

São as reformas de objetivos mais transparentes: buscam tornar legais certas demissões, implantar a "flexibilização" e a terceirização do trabalho, adaptando-o às novas "necessidades" e efeitos da III RI, e, com isso, reduzir o custo do trabalho, eliminando, inclusive, direitos trabalhistas sacramentados em leis anteriores.

Os EUA foram os maiores beneficiários dessas mudanças, porém também sofreriam com o aumento da volatilidade financeira e da instabilidade da produção, mas ainda assim cresceriam, entre 1990 e 2007, bem acima dos países da OCDE, graças aos seus elevados déficits fiscal e comercial financiados pelos países credores.

A década de 1980 representa uma pequena recuperação do crescimento para os EUA, graças à sua já comentada política fiscal. O Japão teria uma taxa ainda alta (4,5\%), enquanto a Europa já mostrava sua desaceleração (2,5\% contra 3,4\% na década de 1970).

A de 1990 daria continuidade ao crescimento dos EUA, mas Europa e Japão despencariam numa recessão. De 2000 aos dias de hoje, as três economias seriam 
fortemente afetadas pela gravíssima crise financeira de 2007-2008, que se prolongaria até os dias de hoje.

A financeirização já havia dado muitos passos, mais do que compensando, via lucros financeiros do capital fictício, o debilitamento do setor produtivo, em especial o da indústria de transformação, a qual, desde a década de 2000 sofreria ainda mais, com preços relativos cadentes no mercado internacional.

A grande exceção seria a China, que recebeu grande fluxo de investimentos externos que estavam na incessante procura por trabalho barato ${ }^{18}$. Com o grande fluxo de IDE, sua própria e elevada taxa de inversão (40\% a 50\% do PIB) e sua competente e controladora política econômica, consolidou a reestruturação e expansão de seu parque industrial na passagem da década de 1990 para a de 2000.

Passou rapidamente, de maior exportadora de bens de consumo não duráveis, a maior exportadora de eletrônicos. Em 2015, seu PIB já era equivalente a $61 \%$ do dos EUA, atingia o primeiro lugar mundial em exportações e o segundo em importações, e, ainda, acumulando cerca de US\$ 3 trilhões de reservas cambiais.

Ao mesmo tempo, ao transferir do campo para a cidade cerca de 500 milhões de pessoas, converteu-se também no maior importador de alimentos e insumos de toda ordem, cumprindo o papel de "locomotiva" do crescimento, notadamente para os países subdesenvolvidos exportadores daqueles bens.

Contudo, o "efeito China" não seria suficiente para conter a crise financeira já anunciada. Ela eclode em 2008 nos EUA, estendendo-se para a maior parte dos países desenvolvidos até 2016, mas ainda com taxas baixas de crescimento. Os efeitos da crise só não foram mais catastróficos porque seus Estados nacionais salvaram seus principais bancos, evitando seu aprofundamento ${ }^{19}$. Mas é necessário dizer que a crise não foi inteiramente debelada, e, aliás, nem poderia ter sido, dado que a expansão do sistema financeiro não foi contida e tampouco se voltou a regulamenta-lo, deixando-se o "animal" solto, para novas estripulias.

Os principais efeitos econômicos da implantação da reestruturação e das políticas neoliberais - excetuada a crise - foram a retomada do crescimento (embora a taxas muito baixas), a continuidade da renovação tecnológica e a elevação da competitividade, mas aos elevados custos da precarização do trabalho, do avanço da desindustrialização "normal" e da prática de políticas de "austeridade" notadamente com os "PIGS" (Portugal, Itália, Grécia - a mais atingida -, e Espanha).

(18) Esse influxo de capital teve origem menos concentrada, dele fazendo parte EUA, Europa, Japão, Coréia do Sul, Taiwan e outros países do sudeste asiático.

(19) Os EUA, praticaram déficits fiscais médios de cerca de 10\% do PIB, entre 2008 e 2013; além disso, nos EUA, a política monetária utilizou quantitative easing, da ordem de US\$ 4,5 trilhões, e na UE e no Japão, atingiram cerca de US\$1,5 trilhões cada. 
Contudo, esses efeitos econômicos desenvolveram, direta ou indiretamente, efeitos políticos e sociais nefastos, que atingiram a maior parte da população, em especial a classe trabalhadora. Tais efeitos, dadas as especificidades de cada país, podem ter tido amplitudes distintas, em termos mundiais e nacionais. E vários deles são na verdade, sequelas deste longo processo de neoliberalização, e se apesentam com um caráter estrutural e de larga permanência. Eles decorrem, ente outras causas, do desemprego; precarização crescente do trabalho, forte diminuição do papel do sindicato; eliminação de direitos trabalhistas e sociais; crise e deterioração do papel do estado e de políticas sociais; perda de sentimento nacional e falso cosmopolitismo; consumismo; perda de solidariedade; insegurança social; aumento da poluição; banalização do crime, da corrupção e da prisão; mediocrização cultural, e outros.

Esses efeitos não serão tratados nesta parte internacional do texto, não só por questão de espaço, mas, principalmente, por sua complexidade e extensão. Lembremos que muitos desses efeitos foram amplamente divulgados pela imprensa internacional, como por exemplo, o elevado desemprego e precarização do trabalho, a piora da distribuição de renda, o crescimento do crime e do uso de drogas, elevado número de prisões, consumismo, individualismo, corrosão da política, e outros. Contudo, além da ressalva feita no parágrafo anterior, sobre as especificidades de cada país, cabe lembrar que as bases econômicas, sociais e políticas dos países desenvolvidos são muito mais resistentes do que as dos países subdesenvolvidos, como se verá na parte final

\subsection{Brasil: circunstâncias internas e a longa crise pós-1980}

O choque norte-americano dos juros e o corte do financiamento externo foram fulminantes para a América Latina, em especial para o Brasil, que mergulhou numa profunda crise entre 1980 e 1983, com o PIB crescendo em média anual de apenas $2,2 \%$ na década, e a indústria de transformação em $0,9 \%$. Do enorme conjunto de investimentos programados pelo regime militar - iniciados ou já em andamento -, a maior parte sofreu paralização, com o que a taxa de investimento, antes em torno de $25 \%$, cairia para a média de cerca de $17 \%$.

A inflação, já de 100\% em 1980, após duplicar em 1983-85, arrefece para 65\% em 1986 graças ao Plano Cruzado (heterodoxo), voltou a subir em 1987, atingindo $1.780 \%$ em 1989, a despeito dos vários "Planos de Combate à Inflação" então postos em prática, quase todos nos moldes do figurino do FMI. A "estatização" da dívida externa privada aumentou ainda mais o gasto público financeiro, com as receitas já debilitadas pelo baixo crescimento e a elevada inflação ${ }^{20}$.

(20) Sobre a "estatização" da dívida eterna, ver Davidoff Cruz (1983). 
A estagnação e as desvalorizações cambiais cortaram as importações, mas a crise e a política de incentivo às exportações expandiram fortemente estas, gerando grandes superávits comerciais, que tinham que ser comprados pelo Estado, para fazer frente ao serviço da dívida externa. Mas isto, ao mesmo tempo que enxugava o mercado de divisas acrescia fortemente a oferta de moeda nacional, anulando, com isso, as tentativas ortodoxas de conter o fluxo monetário e debelar a inflação.

Esta modalidade de ajuste (Ajuste Macroeconõmico dos 1980's) continha inclusive, medidas para sanear as finanças públicas, com cortes do gasto, controle do crédito e do câmbio, e ainda medidas de contensão salarial pública e privada. Contudo, não solucionou nenhum dos problemas para os quais era aconselhada: debelar a inflação, retomar o crescimento, pagar integralmente o serviço da dívida e reequilibrar as contas públicas ${ }^{21}$.

São por demais conhecidos os efeitos decorrentes desses ajustes, mas vale lembrar os principais:

A) econômicos: Além dos citados fracassos acima, cabe lembrar os seguintes: i) constrangimento no processo de acumulação de capital, restringindo o investimento, a introjeção tecnológica e a produtividade; ii) debilitamento e desorganização do Estado nacional; iii) desnacionalização e redução do poder de decisão nacional público e privado de investir; iv) início de nossa desindustrialização, com o peso do valor adicionado da indústria de transformação no PIB caindo de $31 \%$ para $25 \%$.

B) sociais: i) desemprego e queda do salário real; ii) piora na distribuição da renda; iii) deterioração de vários serviços públicos, como por exemplo, educação e saúde; iv) desaceleração dos processos de ascensão social.

São raros os efeitos positivos do período, e talvez o principal deles foi a conscientização política maior, com significativa expansão de movimentos e Partidos Políticos progressistas, que tanto lutaram pelo fim da ditadura e pela retomada da democracia. Lembremos também que a elaboração da Constituição de 1988 - Constituição Cidadã -, que repôs ou introduziu vários instrumentos de ampliação e respeito aos direitos civis e do trabalho, resultou desse mesmo movimento.

Alguns efeitos maléficos da década de 1980 se tornariam cumulativos na de 1990, tornando-a ainda mais problemática do que a anterior. O Neoliberalismo, que já havia entrado em vários países da América Latina, dava mostras de impaciência para ingressar no Brasil. Poucas tentativas se fizeram, mas já em 1989, se dá pequeno

(21) Sobre os principais efeitos econômicos e sociais das políticas macroeconômicas e do neoliberalismo na América Latina e Brasil, nas décadas de 1980 e 1990, ver Cano (2000). 
início da abertura comercial, e na eleição desse ano, o futuro governo para 1990/1994 (Collor e Itamar) anunciava algumas medidas neoliberais genéricas ${ }^{22}$.

Lembremos que nos anos noventa, os países desenvolvidos já haviam avançado na reestruturação de seus parques produtivos, estavam em plena incursão asiática (notadamente na China), e não tiveram grande trabalho para impor a Nova Ordem na América Latina. O problema central para eles não era mais o de receber juros da dívida, mas sim renegocia-la e debelar a inflação, para reconverter a América Latina ao circuito internacional do dinheiro, além de alargar o espaço da globalização e do neoliberalismo.

Os "milagrosos" Planos Anti-inflacionários continuaram até 1993, e a inflação também: $1.480 \%$ em 1990, e de, respectivamente, $480 \%, 1160 \%$ e $2.710 \%$ nos três anos seguintes e em $1.110 \%$ de janeiro a julho de 1994, quando se altera radicalmente essa política, com o Plano Real,

Dados os novos objetivos, era mister debelar a inflação e, para isso, a "engenhosidade" desse plano foi diferente: a ancoragem do nível de preços não seria mais os "repressivos" controles de preços e sim o câmbio valorizado e o orçamento federal para suportar a enorme carga de juros que viria sobre a dívida pública líquida, que chegaria, em 2002, a representar 59,9\% do PIB. Isto, por sua vez, exigiu forte elevação da regressiva carga tributária, insuficiente contudo, para dar conta das amortizações e dos juros da dívida pública.

O novo Ajuste (Ajuste Macroeconômico dos 1990's) agora sob a orientação do BIRD, mantinha algumas regras do anterior, como o corte no gasto público, juros elevados, controle restritivo do crédito e equilíbrio orçamentário. Também constrangeu a política salarial, e a nova forma de correção do salário mínimo manteve grande parte de sua perda real acumulada. Ao contrário do anterior, que desvalorizava o dólar para estimular o saldo comercial para pagar os juros, o novo estimulava as importações, via dólar valorizado e o forte rebaixamento de tarifas e outras restrições.

A taxa média anual do crescimento do PIB, ao longo do período 1989-2002 foi de apenas $1,9 \%$ e a da indústria de transformação, de apenas 0,9\%. Com isto, nossa desindustrialização dava mais um passo, caindo a participação do setor de transformação no PIB, de cerca de $22 \%$ para $20 \%$. As variáveis que mais contribuíram para o aumento do PIB foram as exportações e o consumo das famílias que passa de 76,9\% do PIB em 1989 para 81,3\% em 2002, graças à contenção inflacionária e ao forte barateamento das importações, cujo crescimento relativo foi

(22) Os casos mais notórios foram os de Collor (1989) e FHC (1994) no Brasil, Menen em 1989 na Argentina, Gavíria em 1990 e Samper em 1994 na Colômbia, Fugimori em 1990 no Peru, Perez (reeleito) em 1989 na Venezuela e Alwin em 1990 no Chile. Este último, embora da social democracia - como FHC - manteve a maior parte das reformas neoliberais de Pinochet. Sobre o assunto, ver Cano (2000). 
bem maior do que o das exportações. $\mathrm{O}$ aumento mais expressivo destas, graças à crise e ao baixo crescimento, foi causado pelos produtos manufaturados, cuja participação na pauta passa, de $54,2 \%$ para $60,7 \%$, o ponto mais alto atingido até hoje.

Os principais efeitos econômicos do conjunto dessas reformas, além dos acima mencionados, podem assim ser resumidos:

- expansão da financeirização da economia - o Domínio do dinheiro -, aumentando a valorização do capital fictício em detrimento do produtivo, com lucros exacerbados do sistema financeiro; aumento do endividamento privado e principalmente público; aumento da riqueza do segmento rentier na sociedade. Acrescente-se que foi dada grande autonomia à condução, pelo Banco Central, da política monetária, cambial e creditícia, cuja diretoria, embora não eleita pela população, toma decisões sobre juros, crédito e câmbio, afetando toda a população do país;

- aumento do desequilíbrio fiscal e financeiro do Estado, graças aos encargos da dívida. Em 2001, a Lei de Responsabilidade Fiscal - além de outras determinações -, limitava em $60 \%$ os gastos com pessoal. Porém a "negociação" da dívida dos estados e dos municípios feita em 1995, impôs elevados juros a essa dívida, agravando sobremodo o desequilíbrio das esferas estadual e municipal. Com isso, houve forte rigidez na estrutura orçamentária, a qual, para preservar o pagamento dos juros, "ajustou" os demais gastos correntes e de capital, fazendo cair o investimento público e causando sensível piora nos serviços públicos em geral; ${ }^{23}$

- a abertura comercial: nosso ingresso na OMC em 1994 nos obrigou a escancarar nosso comércio exterior, com forte rebaixamento de tarifas e outras restrições, e, graças ao Plano Real, operar com câmbio valorizado (em 20\% a 30\%), prejudicando seriamente nossa competitividade internacional;

- processo de desindustrialização, que agora, além do debilitamento do investimento industrial, também era atingido pela valorização do câmbio e pela abertura comercial;

- forte aumento da carga tributária, que passou de $28 \%$ para $32 \%$ entre 1994 e 2002, regressiva, não só alterando os custos da produção, como principalmente piorando a distribuição de renda;

- a reforma administrativa, no afã de instaurar o Estado Mínimo, fechou e fundiu vários órgãos, demitiu, afastou e disponibilizou dezenas de milhares de funcionários públicos e alterou direitos de estabilização. Criou as OS - Organizações Sociais -, que substituíram algumas empresas, Fundações e Institutos públicos,

(23) Uma importante discussão e análise sobre o tema está em Oliveira (2009). 
principalmente de pesquisa, que passaram a vender serviços para obter recursos necessários às suas atividades. Criou também dez Agências Reguladoras Nacionais (como a ANP, do petróleo, por exemplo) que regulam e fiscalizam vários dos mais importantes setores da vida nacional, concedendo mandato fixo de seus dirigentes que em geral, vem da área privada do próprio setor -, e cujo objetivo maior é fazer uma "administração técnica" e evitar a "ingerência da política", mas que introduzem a ingerência privada. Essa retirada da "administração" de seus respectivos ministérios, obviamente repassa importante poder decisório às ANs. Essa reforma teve grande contribuição na desorganização do Estado e na perda de interesse público pelo funcionalismo mais qualificado;

- a reforma trabalhista deu alguns passos, sendo aplicada por FHC entre 1995 e 1998, de forma "gradativa", para atenuar as resistências. Suas principais medidas foram: a) instituição de salário "variável", via distribuição de lucros, desfocando a centralidade do salário real e da produtividade; b) revogou a Convenção 158 da OIT, eliminando fatores que inibem a demissão sem justa causa; c) eliminou a indexação salarial, forçando a negociação com as empresas e trabalhadores; d) eliminou a indexação legal do salário mínimo, substituindo-a por reajustes anuais negociados; e) diminuiu a punibilidade das infrações trabalhistas constatadas pelo Ministério do Trabalho; f) várias outras mudanças, como criação do Banco de Horas; jornada de 25 horas semanais com redução de salários; permissão maior para o trabalho temporário; criação das Cooperativas de prestação de serviços (terceirização) profissionais; diminuição do poder e amplitude da ação sindical, e outras;

Como positivos, cito o aumento do tempo de seguro desemprego e o aumento da idade mínima do trabalho do menor, de 14 para 16 anos. Mas, com o baixo crescimento do PIB, e menor ainda da indústria, a precarização do trabalho e o desemprego aumentaram. Este, no setor urbano do país, passou de 4,3\% para $10,7 \%$ enquanto o desemprego aberto da Região Metropolitana de São Paulo passava de $7,4 \%$ para $12,1 \%$.

- a reforma do sistema de previdência, teve como principais mudanças: a) no setor público: para os funcionários em geral, o Tempo de Serviço (35 H e $30 \mathrm{M}$ ) foi substituído, no cálculo, pelo Tempo de Contribuição e os aposentados e pensionistas também passaram a pagar contribuições, de $11 \%$; b) para o setor privado, Tempo de Contribuição e Idade $(65 \mathrm{H}$ e $60 \mathrm{M})$; e outras medidas de menor alcance;

- a privatização de ativos públicos foi anunciada como restauradora da ineficiência estatal, redutora de custos e preços, e geradora de recursos "para o pagamento da dívida", mas a realidade seria bem diferente. Cerca de 100 unidades foram privatizadas, entre empresas, bancos, jazidas de petróleo e outras instituições 
públicas, encarregando-se o Banco Nacional de Desenvolvimento Econômico e Social, para ser seu "gestor", denegrindo sua imagem construtora nacional. Alguns críticos chegaram a pensar que talvez devesse mudar seu nome, para "Banco Nacional de Desestatização".

A quantia apurada pela privatização de ativos federais somou US\$ 46,1 bilhões (o total nacional foi de 68,5), valor equivalente a 1,2\% do PIB médio anual de 1991 a 1998, quantia pequena demais para enfrentar o pagamento da dívida púbica, que, como falei mais acima, atingiria quase 70\% do PIB em 2002! Mas, na verdade, a operação foi ainda mais barata pois:

- a conversão dos valores nacionais em dólar causou mais um alto prejuízo pois a taxa cambial esteve valorizada entre $20 \%$ e $30 \%$ no período;

- cerca de US\$ 8,9 bilhões foram pagos com as chamadas “moedas podres", que eram alguns títulos públicos fortemente desvalorizados - mas que foram recebidos por seu valor nominal integral -, que jaziam principalmente em cofres privados, à espera de incautos ou de especuladores profissionais;

- para "embelezar a noiva", o Estado teve que realizar altos investimentos prévios em várias dessas empresas, que totalizaram o equivalente a US $\$ 23,9$ bilhões, entre 1991 e 1998, que, obviamente, não foram repassados aos compradores;

Se descontarmos do valor total $(46,1)$ : um deságio médio das moedas podres $(4,0)$; uma depreciação cambial de $20 \%(9,2)$; e os investimentos prévios $(23,9)$, restariam apenas a bagatela de US\$ 9 como pagamento "efetivo", além dos US\$16,5 bilhões referentes às dívidas dessas empresas, assumidas pelos novos donos. Contudo, os compradores ainda obtiveram, do BNDES, Banco do Brasil e Fundos de Pensão de funcionários públicos, o equivalente a US\$ 13,3 bilhões, de empréstimos (a juros subsidiados) e venda de ações privatizadas.

O prejuízo foi ainda maior, por outras razões: a) ao contrário do que afirmava o governo. os novos preços, praticados pelos compradores, subiram em relação aos antigos preços públicos; b) parte das compras e gastos que antes eram feitos no Brasil, passaram a ser feitos no exterior, em geral em suas matrizes; c)isso, mais as demandas que passaram a fazer por serviços internacionais (fretes, seguros, financiamentos, etc.) e pela remessa de lucros e de juros de empréstimos, passaram a pressionar ainda mais nosso déficit em Transações Correntes elevando ainda mais nosso endividamento externo.

Mas o maior deles, talvez tenha sido a forte diminuição de controle do Estado sobre setores estratégicos para o desenvolvimento nacional. Ou seja, o processo decisório nacional perdeu mais alguns graus de soberania. O Neoliberalismo nos impôs restrições traumáticas, como as da abertura comercial e da financeira; o câmbio valorizado, para conter a inflação; juros elevados para atrair 
capital externo para enfrentar o desequilíbrio de balanço de pagamentos. Mas o problema adicional e crucial é que o montante de juros atinge tal nível, que consome cerca de $43 \%$ sobre a receita líquida federal (ou cerca de $8 \%$ do PIB), constrangendo fortemente a inversão e o gasto corrente públicos.

Isto é uma verdadeira "camisa de força” para a política econômica, impedindo ou dificultando a realização de suas políticas específicas, dado que estas não conseguem compatibilizar suas metas e instrumentos com os da macroeconomia. Abertura e câmbio barato estão desindustrializando o país, embora tenhamos construído várias políticas industriais nos últimos anos. Como nossa dependência externa aumentou sobremodo, grande parte das decisões de investir passou ao capital externo, o qual, por exemplo, poderá ou não estar interessado em atender objetivos fixados por uma política regional ou industrial.

Mas é necessário lembrar que isso não foi uma imposição via uso de força, e sim uma deliberada cessão gratuita de soberania nacional. Nesse sentido, lembremos que China, Rússia e Índia foram s únicos países a recusarem abrir suas contas de capital do Balanço de Pagamentos; Nigéria e Tanzânia são outro exemplo, ao recusarem, recentemente, acordos de abertura e livre comércio com os EUA e a EU, para proteger seus parques industriais.

Essa é também a razão básica que explica a radical mudança de nossas outrora (até 1980) altas taxas de crescimento para as medíocres dos últimos 36 anos, que nos colocaram num verdadeiro modelo de voo da galinha, com a taxa de inversão (média e industrial) se reduzindo e piorando sua estrutura.

É preciso entender que o insucesso de várias políticas específicas - a regional, p.ex.- não se deve apenas porque as instituições públicas que a regem tenham se debilitado, ou que tal política contenha algumas inconsequências, mas porque os interesses que antes a envolvia estão agora esgarçados. Ainda que tal política figure na Agenda Pública, é mais retórica do que proposta decisória.

Mais grave, é que as estruturas de poder mudaram, com o que a dominância sobre o padrão de acumulação, com essas reformas, passasse para o sistema financeiro. E esse domínio também se dá na valorização do capital: hoje, os balanços das grandes empresas internacionais (e também de várias nacionais) mostram uma perigosa proporção de cerca de 2:1 dos lucros financeiros sobre os operacionais, o que explica a menor disposição do empresário privado, em investir no setor produtivo ou na infraestrutura, e cada vez mais aplicar o capital no financeiro.

Dessa forma, tornou-se difícil encontrar empresários que aceitem investir em infraestrutura e na produção, ou governos que pretendam exercer uma ação pública "desenvolvimentista". 
Entre 1980 e 1994, o fracasso das políticas anti-inflacionárias e a elevada dimensão da própria inflação, de um lado, e a desorganização do Estado, de outro, fizeram com que agentes públicos, políticos, academia e mídia, concentrassem suas atenções no curto prazo, melhor dizendo, no cotidiano, nos juros, nos preços e no câmbio. O longo prazo foi afastado, reduzindo-se sobremodo o ato de pensar em “objetivos nacionais públicos (ou privados) de longo prazo".

Com o Plano Real, isso foi institucionalizado, dado que os grandes objetivos da política econômica eram o de manter baixa a inflação e o do equilíbrio das contas públicas. Como não se preocupava com o longo prazo, o próprio Ministério do Planejamento, antes um dos mais atuantes, foi perdendo espaço, convertendo-se, até hoje, num "Ministério das Contas Públicas". O Neoliberalismo, dessa forma, mostrava não ter compromisso com o futuro do país, nem, muito menos, com o de sua população. Assim, economia e sociedade também eram obrigadas a diminuir suas expectativas futuras.

O constrangimento do gasto público corrente piorou muito os serviços públicos. A taxa de desemprego cresceu e o aumento de ocupações se deu, basicamente, em serviços, e em trabalho precarizado. Ao final do período 19892002, a perda de expectativas com o futuro não foi total, haja vista as eleições marcadas para outubro-novembro de 2002, onde surgia uma "luz no fim do túnel" com a perspectiva de uma vitória de Lula. Essa era a perspectiva da maior parte da classe trabalhadora e da militância política progressista.

Mas em 22 de junho de 2002, Lula assinou a Carta ao Povo Brasileiro, documento que, embora de caráter progressista, comprometia o candidato a "respeitar contratos e obrigações do governo brasileiro" numa clara alusão ao problema da dívida pública externa e interna, tentando com isso acalmar o sistema financeiro, ao mesmo tempo que prometia uma política desenvolvimentista e de justiça social, junto ao eleitorado. Foram raros os críticos que entenderam que aquilo, na verdade, era muito mais um acordo com o sistema financeiro e não mera promessa eleitoral.

Os dois mandatos de Lula - 2003 a 2010 -, apresentam importantes contradições em relação ao Neoliberalismo. De um lado, continuou cumprindo com quase todos os ditames da política macroeconômica, e de outro, foi progressista em relação às políticas sociais, a alguns investimentos de infraestrutura e à política externa.

Teve a coragem de: dar forte reajuste ao salário mínimo real; regulamentar a Constituição de 1988, estendendo esse benefício ao setor rural atingindo cerca de 18 milhões de pessoas; aumentar, de $50 \%$ para $100 \%$ do salário mínimo, o Benefício de Prestação Continuada (idosos e inválidos); ampliar consideravelmente o programa de renda mínima (Bolsa Família), levando comida a cerca de 45 milhões 
de pessoas. Além disso, implementou o Programa Luz para Todos e - criou, em 2009, o Programa Minha Casa Minha Vida, dando fortes subsídios para a população de baixa renda.

Ao final de seu governo, 35 milhões de pessoas haviam deixado a linha de pobreza da distribuição de renda. Para isto, sem dúvida, também colaborou o aumento da fiscalização do Ministério do Trabalho e seus incentivos e estímulos para a formalização dos contratos de trabalho. Contudo, há que ter presente que essa melhoria na distribuição de renda não se deu por mudanças estruturais (por exemplo, via reforma agrária, ou por fortes mudanças na estrutura ocupacional, e sim por decisões políticas que podem ser alteradas por um governo não progressista.

Sua política externa foi muito importante para aumentar nossas exportações a países com os quais tínhamos comércio muito modesto - especialmente na Ásia e na África -, estimulando e financiando o capital nacional para a realização de investimentos - notadamente de infraestrutura- no exterior. No plano político, sua atuação junto a governos mais progressistas da América Latina (Venezuela, Equador, Bolívia e Cuba) foi muito importante para apoiar esses países, estreitar nossas relações e dar continuidade ao Mercosul, quadruplicando nossas vendas para essa área, entre 2002 e 2010.

Contudo, o compromisso assumido ("respeito aos contratos") e as circunstâncias externas e internas que envolveram seus mandatos, não permitiram que seu governo se livrasse da "camisa de força" acima mencionada. Assim, os juros permaneceram muito altos e o câmbio se manteve muito baixo, em quase todos os anos de seus mandatos. Aí a "surpresa": como pode o país pagar (parte) dos juros e ainda crescer?

Ocorre que, além dos efeitos econômicos positivos decorrentes de sua política social, seu governo foi bafejado por fortes "ventos de popa". Isto é, o boom ocorrido na China durante os noventas e na primeira década do século XXI, elevou rapidamente sua demanda internacional por alimentos e matérias primas, aumentando não só as quantidades requeridas, mas, principalmente os preços.

Foi assim que nossas exportações cresceram, entre 2002 e 2010, à taxa média anual de 16,3\%, dinamizando, principalmente o setor agrícola, o mineral e secundariamente os serviços. Como as importações cresceram ainda mais (21\%), o setor serviços foi ainda mais beneficiado, crescendo acima dos demais setores e do PIB, cuja taxa foi de 4,0\%. A indústria de transformação, contudo, foi o setor que menos cresceu (3\%) não se desviando da rota da desindustrialização. O governo elaborou, no período, políticas setoriais bem estruturadas, como a Regional e a Industrial, sem contudo lograr bons resultados, face à "camisa de força".

Os elevados saldos comerciais do período minimizaram os déficits em transações correntes, que ainda assim totalizaram US\$ 46 bilhões, soma menor do 
que a da década perdida, e muito inferior ao do período 1989-2002, que atingiu a soma de-US\$ 186 bilhões.

Uma das contradições em relação ao neoliberalismo, foi a criação do crédito consignado a trabalhadores e aposentados - com desconto direto na folha de pagamentos -, que permitiu um crescimento expressivo do Consumo das Famílias $(4,4 \%)$. O total de empréstimos ao setor privado, que estava contido no equivalente a 24\% do PIB em 2002, foi elevado, chegando a 50\% em 2010.

Ainda que o crescimento do PIB não tenha sido exuberante, proporcionou um aumento da arrecadação fiscal que suportou a carga de juros e as políticas sociais. Permitiu uma modesta retomada da Taxa de Investimento - de cerca de $16 \%$ para $19 \%$-, com inversões principalmente em infraestrutura de transportes e de energia. Conseguiu também diminuir fortemente a taxa de desemprego urbano do Brasil, de $11,2 \%$ em 12/2002 para 5,9\% em 12/2010.

A crise internacional de 2008 ameaçou abalar esse ambiente, com queda do PIB em 2009, mas o governo praticou uma política anticíclica, especialmente para a indústria, evitando a continuidade da recessão. Contudo, os ares seriam outros, com a extensão da crise internacional para a Europa e Ásia, desacelerando ainda mais o crescimento e o comércio internacional. Os ventos do barco de Dilma Rousseff soprariam da proa para a popa, em seu primeiro mandato (2011 a 2014), atravessando tempestades durante o primeiro ano de seu segundo mandato, e terminando seu governo, em 2 de dezembro de 2015, com seu afastamento pelo impeachment.

Dilma acreditava que baixando os juros e ampliando a política anticíclica, o país voltaria a crescer. Esqueceu do câmbio e parece não ter se dado conta da profundidade da crise externa. Os juros (Selic) baixaram, de 11\% em 2011, para 10\% no início de 2012 e para 7,5\% entre 4/2012 e 8/2013, quando o câmbio subiu e a inflação começou a ameaçar. Os juros voltaram a subir para 11\% em 2013 e $14 \%$ em 2015.

Embora sua política anticíclica tivesse aumentado o número de setores beneficiados com incentivos fiscais e com desoneração de encargos sociais na folha de pagamento, isto não pode dar conta da crise, e ainda agravou a situação fiscal. As pressões políticas e econômicas aumentaram e em 2015, Dilma sucumbe e adota uma política ortodoxa, que agravou ainda mais a crise ${ }^{24}$.

Ainda que o investimento tenha crescido à taxa média anual de $3,3 \%$ a do PIB foi de apenas $2,2 \%$ e a da indústria de transformação, de $-0,5 \%$; era a fase de descida do voo da galinha. No quadriênio 2011-2014, as exportações cresceram à média anual de apenas 1,5\%, mas a das importações, foi de11,3\%, atingindo em cheio o setor industrial. O desequilíbrio externo cresceu, acumulando saldos em

(24) Sobre as políticas sociais no período, ver: Gentil (2015) e Fagnani (2015). 
transações correntes de -US\$279,5 bilhões (!), e a dívida externa bruta passou de (em bilhões de dólares), 453 em 2010 para 712 em 2014.

Dilma deu continuidade às políticas sociais de Lula, notadamente a da habitação. Nos dois governos do PT (2003 a 2015), foram construídas cerca de 4 milhões de residências, tanto quanto nos 21 anos do regime militar. O desemprego urbano do país, que era de 5,9\% em 12/2010 aumentou pouco, até 12/2015, para $6,9 \%$, enquanto o desemprego aberto da RMSP, nas mesmas datas, passou de $8,8 \%$ para $10,9 \%$. O drama viria em 2016 , quando essa última taxa sobe para $17 \%$ e para $18,5 \%$ em $3 / 2017$ !

Parte do legado da abertura comercial e financeira pode ser sintetizado nos seguintes dados, para os anos 2002, 2010 e 2014, em US\$ bilhões:

i) ativos brasileiros no exterior: $114 / 580 / 768$;

ii) ativos estrangeiros no Brasil: 341/1.485/1.541;

iii) passivo líquido (ii-i): 227/906/793;

iv) dívida externa bruta: $236 / 453 / 712$;

v) reservas totais: $36 / 288 / 364$.

As reservas cresceram, mas à custa da enorme entrada de investimentos em carteira e de empréstimos, e não de saldos em transações correntes, pouco reduzindo nossa vulnerabilidade externa. Há que considerar que o período 1980-2002 foi o precursor do aumento da dívida que se torna uma "bola de neve"; no de 2002-2010, graças ao programa de investimentos (infraestrutura) do governo e aos estimulantes preços dos ativos nacionais, o IDE salta (em US\$ bilhões) de 100 para 680 e, ainda, explodem os investimentos em carteira, principalmente compras de títulos da dívida (maiores juros do planeta) e as baratas ações de empresas brasileiras. Em 2010-2014, com o agravamento da crise internacional, o movimento arrefece, com aumentos moderados no IDE, em títulos da dívida e em empréstimo e financiamentos, caindo muito o movimento de ações.

A desnacionalização avançou ainda mais no período, e esse efeito nefasto atingiu em especial à indústria de transformação, já fortemente debilitada, e que teria sua participação no PIB reduzida para apenas $12 \%$ em 2014. Com isso, o poder decisório nacional sobre uma possível reversão da desindustrialização desse estratégico setor, diminuía fortemente ${ }^{25}$.

\section{Principais transformações políticas e sociais}

Nossa História mostra que o Colonialismo, Patrimonialismo e Escravidão deixaram marcas profundas em nossa Formação Social, e esses fatos geraram efeitos nefastos tão profundos, que muitos deles continuam a se reproduzir na atualidade.

(25) Ver a respeito Cano (2014). 
Obviamente, tais fatos não serão aqui tratados, mas apenas quero deixar claro que não são apenas os fatos recentes enunciados nestes dois últimos tópicos os causadores únicos dessa desorganização social.

Assim, voltemos a eles. O sentido do Neoliberalismo e da Globalização, embora aparentemente novos, são fatos que o Capitalismo já havia criado antes, através da expansão do comércio internacional durante o século XIX (com a doutrina do livre-cambismo e das vantagens comparativas) e de sua ideologização liberal. É verdade que isto se iniciou primeiro com o Império Britânico, porque os futuros países industrializados eram todos fortemente protecionistas, enquanto davam seus primeiros e difíceis passos na industrialização.

A História nos ensina que ao mesmo tempo em que a tecnologia e o progresso técnico causaram transformações positivas para a sociedade, causaram também muita dor e sofrimento pelo desmantelamento da primitiva sociedade da solidariedade e da reciprocidade e do sofrimento pela submissão do trabalho a baixos salários. Ela também relata que, notadamente entre o final do século XIX e o final da Segunda Grande Guerra, o capitalismo, por uma série de razões que aqui não podem ser tratadas, foi obrigado a tomar um "banho de civilização", regulando e concedendo direitos ao trabalho, permitindo os Sindicatos e Partidos políticos Progressistas, concedendo direitos civis, e finalmente instituindo políticas públicas de welfare state.

Mas a partir da década de 1970, estamos vivendo um processo cada vez mais regressivo, desde a instauração do Neoliberalismo e da Globalização, que, em moldes "modernos", vem destruindo parte daqueles direitos conquistados, alterando nossas estruturas e instituições, e criando um clima geral de desorientação e perplexidade. Para tanto, vem submetendo a maior parte da humanidade, às Reformas e Regras acima relatadas. Resumidamente, vejamos os principais efeitos políticos e sociais nocivos e seus desdobramentos mais gerais, fortemente influenciados pelas reformas neoliberais e pela globalização:

i) ninguém sabe melhor do que as lideranças capitalistas, que o Estado não só é o Pronto Socorro para suas crises, mas principalmente uma espécie de "guia" para a tomada de decisões do investimento privado. Mas elas querem a todo instante, se ver livres das regulamentações e controles do Estado; querem que o Estado deixe de ser "perdulário", por cuidar das populações de menor renda, para poupar recursos orçamentários e aloca-los em algo mais "objetivo" ao capital. Por isso, a regra número um do Neoliberalismo é a do Estado Mínimo, e a restauração da supremacia do mercado;

ii) o Pensamento Único tenta nos impor a ideia de que o sentido do Nacionalismo é coisa do passado, arcaico, e que a modernização e desenvolvimento são frutos da Globalização e da internacionalização de todos os países, e para isso: 
faz a falsa promessa de um acesso competitivo a todos os mercados do planeta, diz que isso será alcançado com o uso de novas C\&T, - e vários de seus gurus afirmam que ela é um "bem livre" -, pregam a ascensão, pela concorrência, a um novo cosmopolitismo (o "primeiro mundismo"). Essa ilusão se estendeu e desdobrou a países, regiões e cidades, que passariam a ser "competitivos entre si";

iii) o Neoliberalismo estendeu, o quanto lhe foi possível, a ideia da mercantilização geral, não só de bens e serviços - notadamente da cultura, saúde e educação -, mas também de direitos e obrigações. A regra geral é que "tudo tem que ser objeto de compra, preço, lucro ("eficiência privada"), e venda;

iv) como o capitalismo se encontrava (entre 1970 e 1980) com lucros deprimidos, e a Terceira Revolução Industrial reduziria seus custos e preços, abriuse um espaço ainda maior ao capital fictício, que, com seus lucros financeiros, compensou a contração de lucros produtivos e deu mais do que "sete fôlegos" ao capitalismo "renovado". Foi a vitória do Império do Dinheiro!;

v) tudo, nesse novo sistema, é efêmero: marcas, produtos (consumismo), processos, inovações, trabalho (precarização), e instituições, nascem e morrem com grande rapidez A redução do Estado, cortando o Investimento Público, aumenta ainda mais a incerteza sobre o futuro. As principais preocupações da política econômica se concentram no curto prazo -os preços, o juro, o equilíbrio das contas públicas, o câmbio -. Não há, praticamente, o longo prazo. Aliás, o efêmero não tem futuro.

Vejamos, num exercício de reflexão, mas também de observação da realidade, como esse veneno se espalha por toda a sociedade, atingindo praticamente todas as suas instituições.

\section{- Estado Nacional}

Como vimos, ele foi pesadamente atingido pelos efeitos cumulativos da crise dos oitentas, do Neoliberalismo, da Globalização e, ainda, por erros praticados por nossos dirigentes. Entendido aqui como o conjunto dos três poderes (Executivo, Legislativo e Judiciário), converteu-se no maior gerador e difusor da desorganização e ineficiência dos serviços públicos em geral, disseminando seus efeitos junto às principais instituições do país.

Foi debilitado em termos fiscais, financeiros, administrativos e políticos, ampliando assim o desgoverno, quebrando o equilíbrio entre os Poderes Constituídos e estimulando com isso a burocratização maior, a generalização da corrupção, a falcatrua e o uso descarado da mentira. Poderíamos citar muitos exemplos, mas fico apenas em quatro deles: 
a) o fato do Executivo manter, até hoje, vários ministros indiciados em crimes de corrupção no Estado;

b) a raridade de pedidos de impedimento por parte de vários juízes, em casos em que a necessidade do impedimento é transparente;

c) no início de 2017 o IBGE mudou a base de dados dos setores de vendas a varejo e de serviços, de 2011 para 2014, conseguindo, com isso, a "proeza" de transformar as taxas negativas de crescimento de 12/2016 para 1/2017, já antes divulgadas $(-0,7 \%$ e $-2,2 \%$, respectivamente), em positivas $(5,5 \%$ e $0,2 \%)$, tentando alentar os cânticos e louvores pela "recuperação" da economia... ${ }^{26}$;

d) para vender a ideia de uma futura "catástrofe" nas contas da Previdência Social, o governo projetou o crescimento da população, usando dados da PNAD de 2014 (que, como se sabe, sobrestimam a população) e que continham ainda erro de projeção na população idosa, sobrestimando-a.

No que tange à política, lembremos que a ditadura militar já havia marginalizado grande parte de nossos representantes no Congresso Nacional e os fatos posteriores mostram uma inequívoca e gradativa piora do plantel. Sua constituição hoje é fracionada em blocos de interesses diversos, mas que se juntam sempre nas votações de temas conservadores e reacionários ${ }^{27}$. Acrescente-se a corrosão da política e de seus principais partidos, a judicialização da política e o crescente uso político pelos aparelhos de repressão. Uma deplorável e insólita demonstração desse estado de coisas foi o ato da votação do impeachment (17 de abril de 2016) pela Câmara Federal, um verdadeiro (mau) espetáculo circense barato.

\section{Mídia}

Não se poderia esperar da Mídia, outro comportamento diferente daquele conivente - salvo raras exceções -, que teve durante a ditadura militar. Ela aprofundou e estendeu ainda mais essa conivência com o poder, reproduzindo à larga e acriticamente, as "pós-verdades" emanadas por aqueles que mantem sua sobrevivência financeira. Seria necessário fixar algumas regras para o seu funcionamento democrático, mas o governo Lula engavetou seu próprio Projeto de Regulamentação da Mídia. Como a maior parte da classe média e também do Judiciário, demonstra, explicitamente, concentrar seu ódio nos partidos progressistas, notadamente em Lula e no PT.

\section{Empresário}

Esse segmento social também foi contaminado, aumentando sua descrença no Estado, defendendo cada vez menos os interesses nacionais, e parte de seus

(26) Matéria extraída de Carta Capital, n. 950, 3 maio 2017, p. 16-22.

(27) O Brasil atualmente tem 35 partidos, 28 deles com representantes eleitos na Câmara dos Deputados. 
membros aderiu ativamente à corrupção. A retirada quase total do Estado no processo de acumulação de capital e a adesão empresarial ao credo da acumulação financeira, aumentou-lhe o risco da incerteza e tirou-lhe a expectativa de futuro. A especulação financeira tornou-se mais estimulante do que produzir mercadorias.

\section{Trabalhadores}

Com o aumento do desemprego e da precarização do trabalho cresce a competição entre os trabalhadores, afrouxam os movimentos grevistas e diminui a sindicalização, reduzindo o poder político da classe. Isto também costuma causar desalento na militância política trabalhadora. O aumento do número de anos de estudo, nessa situação, também causa um certo desapontamento, face ao desemprego que também atinge trabalhadores mais qualificados, reduzindo seus salários e dificultando sua ascensão social. Essas situações, quando prolongadas afetam sensivelmente as relações pessoais e afetivas.

\section{Sociedade}

Ela é atingida como um todo, pelos efeitos mais "gerais", ainda que de forma diferenciada, por classe social, renda, educação, credo religioso, e identificação política ou ideológica. A acelerada competição (por emprego, educação, ou outra), consumismo, individualismo e insegurança, quebra laços de solidariedade e favorece a corrupção, a contravenção e o crime.

Essa situação de crescente insegurança e impunidade promove a descrença no Estado e em todas as suas instituições, no grande número de políticos "despreparados" e corruptos; na polícia, que "só prende pobres e negros"; no juiz que solta criminosos e corruptos; no hospital público que não tem vagas e "o doente morre na porta"; no péssimo transporte coletivo; na "fraude" do sistema educacional; nas fraudes e falsificações de vários produtos de consumo, e outras mazelas.

$\mathrm{O}$ alto desemprego, a grande deterioração do emprego e dos serviços públicos, a reduzida expectativa de futuro, o crescente consumismo, - mas não para todos -, a competição, a escandalosa impunidade às "altas rodas", aumentou ainda mais a desorientação da população, estimulou a droga, a contravenção e o crime ${ }^{28}$. Este último - mesmo excluindo o grande número de assassinatos de jovens pobres e negros - foi banalizado, dado o aumento de certas ocorrências, como o parricídio, o filicídio, o estupro com morte, e de formas praticadas de barbaridade criminal.

(28) Conforme o Levantamento Nacional sobre uso de Álcool e Drogas (Inpad-Unifesp) o consumo de cocaína e crack tem crescido mais do que a média dos países do mundo. Por outro lado, a OMS divulgou que entre 2006 e 2016 o consumo de álcool no Brasil aumentou 43,5\%. 
A mercantilização generalizada, o consumismo e esse desalento geral abriram as portas para uma mediocrização em vários segmentos da produção e principalmente do consumo de serviços. Vejamos alguns exemplos:

- mediocrização no futebol: já não há mais craques, pois todos foram exportados para o Império do Dinheiro. Os "bons jogadores" que aqui ficaram cometem verdadeiras barbaridades nos jogos, havendo pouca regularidade na qualidade durante a sequência dos jogos. Nunca vi, em toda minha vida, tantos goleiros defenderem tantos pênaltis: são melhores do que os do passado, ou são os atacantes que não tem mais a maestria necessária de um bom batedor? O que falar dos inúmeros passes errados durante as partidas? E dos escanteios cobrados com erros grosseiros? Não esqueçamos que, pelo menos nos clubes grandes, ganham mensalmente algumas centenas de milhares de reais! Lembremos, ainda, que a cúpula do futebol brasileiro hoje, graças a décadas de corrupção praticada nesse esporte, está presa ou fugindo da polícia internacional;

- mediocrização da música popular brasileira: que saudades sinto da (excelente) música popular brasileira, do samba, do chorinho, do baião, da bossa nova, de Pixinguinha, Noel, Chico Buarque, Luiz Gonzaga e tantos outros! Quando fazemos uma viagem de carro, é uma tortura percorrer o dial do rádio em busca da boa música. Ao que tudo indica, a sociedade trocou aquelas e aqueles, por outros, preferindo hoje o sertanejo inautêntico, o forró eletrônico e outras bregas.

- mediocrização da Academia: a (má) educação foi um vetor importante nas transformações do país desde as décadas de 1960 e 1970, quando a ditadura militar se apropriou do projeto de Reforma do Ensino que fazia parte das Reformas de Base do final dos cinquentas e início dos sessentas. Porém a oferta desse serviço pretendeu impor um caráter de formação técnica ao ensino e minimizar a formação humanística, além de incentivar sua privatização ${ }^{29}$.

Em 1976 a Capes criou o Sistema de Avaliação da PG, reforçado pela "ajuda americana" do Acordo MEC-Usaid e a partir daí a PG cresceu e se disseminou pelo país, ampliando as vagas e concedendo bolsas de estudo. Para isso, desenvolveu um sistema de pontuação para avaliar os professores e os cursos, sistema que foi gradativamente perdendo seu caráter qualitativo, instituindo a quantificação de produção, como critério maior de avaliação, instaurando-se o produtivismo na Academia, como meio para se obter mais verbas de pesquisa e mais bolsas de estudos $^{30}$.

(29) A participação do setor privado no total das matrículas do ensino superior em 2015, atingiu 87,5\%, segundo o MEC.

(30) A "quantificação" não ficou só nisso, pois é a partir dos setentas que o quantitativismo foi disseminado na economia, juntamente com o modelismo, em detrimento do conteúdo político, histórico e social. 
Com isso, o professor orientador passou a assinar artigos com seus orientados, "multiplicando" sua produção e as famosas citações bibliográficas. Como a quantidade cresceu rapidamente, tornou-se quase impossível ler criticamente essa produção. Isso deu azo à proliferação de artigos com erros e fraudes cometidos por pesquisadores, "endossados" pelo orientador. A Universidade Pública hoje, já conta com vários processos criminais (inclusive no exterior) contra alguns professores e pesquisadores já notificados ${ }^{31}$.

Em 1998 a Capes criava o Qualis, um ranqueamento de revistas internacionais (pontos mais altos) e nacionais, deturpado em algumas áreas, que ampliou ainda mais o problema: passamos a ter verdadeiros "campeões" na produção de muitos artigos, que ninguém, ou muito poucos os leem. Pior ainda, a Academia introduziu a pontuação quantitativa praticamente em todos procedimentos de avaliação de mérito, obrigando o corpo docente a uma verdadeira Olimpíada da Irrelevância, substituindo a Senioridade por Mérito, como se fazia antes, pela Senioridade do Pontinho.

O quantitativismo, em especial o econométrico, invadiu a área de Ciências Humanas, também nos marcos dos setentas, principalmente na Economia, tentando "explicar" a realidade, com o uso de modelos matemáticos em geral abstratos e incapazes de examinar a complexidade dos fenômenos sociais É a tentativa "pedagógica" da alienação e da despolitização. A Economia foi intoxicada pela macroeconomia da miséria ${ }^{32}$.

\section{Família}

Como não poderia deixar de ser, a família seria atingida por esse longo processo, em seus valores éticos, em sua segurança, em seu sentimento contra a impunidade, em seus costumes, e na tolerância familiar. O consumismo de eletrônicos de comunicação e entretenimento reduziu fortemente sua convivência coletiva, individualizando e segregando seus membros. Isso fatalmente atingiria os padrões educacionais familiares, que se deterioraram.

Os pais, duas décadas antes ainda tinham uma perspectiva de futuro para seus filhos: os das classes de menor renda, via mais educação e melhores empregos; os da classe média, via educação superior e continuidade do tipo de ocupação dos pais. Mas as transformações da estrutura econômica, a crise, e as mudanças no mercado de trabalho foram reduzindo aquelas perspectivas. Seus filhos, quando atingem a idade adulta, também as perdem, diante da situação social do país.

(31) Sobre o produtivismo na Academia, ver: Sguissard (2015) e Wood Jr. (2015).

(32) Tomo emprestada esta expressão usada por Belluzzo e Galípolo (2017, cap. V). 
A melhora na distribuição de renda entre 2003 e 2014, com a subida nos rendimentos das classes de menor renda e o rebaixamento relativo da pequena e média classe média (e em vários segmentos também absoluto), aumentou a desorientação e o sentimento de perda da segunda, criando alguma expectativa, pequena, na primeira. Mas isso fez crescer o ódio latente das classes médias, pelas políticas sociais para as classes de baixa renda, mesmo quando meramente compensatórias. Esse desalento acaba desaguando no terreno político do reacionarismo e na condenação aos partidos progressistas.

\section{$4 \mathrm{E}$ o futuro?}

O ano de 2014 foi difícil para o governo, dado o aumento da inflação para $6 \%$ - o que fez o Banco Central elevar a SELIC de 7,5\% para 11\% -, o irrisório crescimento do PIB $(0,5 \%)$, mais um tropeço da indústria de transformação (cai -4 $\%$ ) e a difícil campanha pela reeleição, que ganhou no $2^{\circ}$ turno, com 51,6\% dos votos.

O quadro se agrava em 2015, subindo a Selic para $13 \%$ - ainda assim a inflação foi a $11 \%$, o PIB caindo $(-3,8 \%)$ e a indústria levando uma queda ainda maior. A situação política foi se agravando até surgir o pedido de impeachment em 2 de dezembro de 2015, seu afastamento em 12 de maio de 2016 e a cassação de seu mandato em 31 de agosto de 2016, quando o vice Temer a substituiu.

A Coordenação desse processo por um juiz do STF certamente para tentar dar um ar de seriedade -, não pode evitar o ridículo da farsa jurídica ali montada. $\mathrm{O}$ governo Temer desde o início não teve o necessário respaldo moral, e, poucas semanas após esse golpe parlamentar, teve de substituir três ministros, por razões éticas e indiciamento por corrupção, e em 26 de maio de 2017, demitiu o novo ministro da Justiça, por razões semelhantes e também por incompetência ${ }^{33}$.

Em 2016, a Selic foi aumentada para 14\% e a inflação se reduziu a 6\%, mas o PIB teve outra queda $(-3,6 \%)$ e a indústria ainda pior. Como a economia não dava mostras de qualquer melhoria a SELIC foi sendo baixada até atingir 11,25\% em abril de 2017, momento em que os poucos indicadores econômicos não davam mostras de nenhuma recuperação segura.

Nem poderiam, dado que a nova política econômica colocou em prática drásticos cortes de gastos, principalmente do investimento público. Entre as principais medidas adotadas, já estão aprovadas a PEC 241/2016, que congela por 20 anos o orçamento federal, cortando não apenas gastos correntes, mas reduzindo também o investimento e a PLC 257-2016 - cuja versão mais dura é a original,

(33) Até o momento do início da "turbulência política" de 17 de maio de 2017, oito de seus ministros estavam citados ou indiciados pelo STF em crimes de corrupção. 
enviada por Dilma em 3/2016 - que também objetiva o corte dos gastos sobre os orçamentos estaduais e municipais, centrando suas medidas sobre o funcionalismo desses entes, que teria que aumentar sua contribuição previdenciária, de $11 \%$ atuais para $14 \%$.

Além disso, estão em tramitação no Congresso as Reformas da Previdência e a do Trabalho. A primeira alega um déficit atual que não existe de fato, e que projeta para 2060, uma "catástrofe" em grande parte construída graças a "erros" grosseiros na projeção da população e do déficit na Previdência. Se aprovadas, ambas retirarão direitos dos trabalhadores, aposentados e pensionistas. A do Trabalho, especificamente, pretende conter a Legislação Trabalhista atual e o sistema da Justiça do Trabalho, além de promover a maior precarização do emprego no país. Temer tem usado uma forte campanha publicitária para tentar enganar a opinião pública, afirmando o absurdo de que elas possibilitarão uma grande criação de empregos, para uma economia que hoje tem um volume de cerca de 14 milhões de desempregados.

Encontram-se também em tramitação ou elaboração, algumas decisões que mostram claramente o caráter entreguista e corrupto de seu governo ${ }^{34}$ :

i) usa o pretexto de um suposto déficit na previdência, mas pouco faz para cobrar a dívida previdenciária das empresas e instituições privadas, estimadas hoje em cerca de $\mathrm{R} \$ 450$ bilhões;

ii) idem, idem, porque ao mesmo tempo, para ganhar o apoio de govenadores e prefeitos para a votação da reforma, propõe refinanciar as dívidas dos governos estaduais e municipais, deixando de arrecadar cerca de R $\$ 30$ bilhões, só com os Municípios;

iii) idem, idem, mais duas tramoias estão em andamento: renegociação e abatimento da dívida dos ruralistas no Funrural (R \$10 bilhões) e do Super Refis (MP 766) tributário de empresas ( $\mathrm{R} \$ 23$ bilhões). Para esta última, a Câmara constituiu uma Comissão Especial de 48 membros, dos quais 22 são devedores, legislando em causa própria, portanto;

iv) já anunciou a abertura de licitações para a venda de vários campos de petróleo do Pré-Sal, prejudicando com isso não só a Petrobrás, mas principalmente nossos projetos de industrialização daquelas jazidas;

v) pela MP 759, pretende "regularizar" as terras da União na Amazônia Legal e a regularização fundiária urbana, abrindo espaço para um aumento do desmatamento no Norte do país;

(34) As cifras abaixo citadas foram extraídas de matéria do O Estado de São Paulo, 21 maio 2017, p. B5, e os "projetos" teriam sido negociados antes de 17 de maio de 2017. 
vi) ainda no final do governo Dilma, o estratégico satélite brasileiro -cobrirá toda a América do Sul e as jazidas petrolíferas da "Amazônia Azul"- ficou pronto e Temer inaugurou seu lançamento em abril último. Ele cumprirá, além da expansão da banda larga, objetivos militares do Brasil. A propriedade é estatal (Telebrás $70 \%$ e Governo - área militar - 30\%). A má notícia é que o Ministro das Comunicações está tramando sua privatização (os $70 \%$ da Telebrás), de forma fraudulenta, segundo a imprensa, sendo mais um caso de corrupção e entreguismo;

vii) mais um ato entreguista: o governo está abrindo o acesso a estrangeiros para aquisição de terras agrícolas.

Como se vê, boa parte do resultado primário que o governo pretendia fazer, com a PEC 241, já foi gasta com o "pagamento" a essas quadrilhas, significando com isso, que as costas do povo terão que ser ainda mais torturadas.

$* * *$

Encerrei este texto em 29 de maio de 2017, doze dias após a divulgação de uma gravação de áudio clandestina (gravador no bolso) feita por Joesley Batista maior sócio proprietário da JBS, a segunda maior empresa do país, pelo menos até aquela data -, em reunião oficial (embora "camuflada" por ocorrer na garagem do palácio) concedida por Temer. Nela, além de confessar suas bravatas em comprar juízes, promotores e outros funcionários, conseguiu fazer com que o Presidente da República desse seu "de acordo" para que o empresário continuasse a prover "mesada" ao ex-deputado Eduardo Cunha - há cinco meses na cadeia - para mantêlo quieto, para não fazer delações!

O rebuliço causado por essa gravação foi muito grande e aprofundou a crise que cerca Temer desde o início do impeachment. Para salvar seu pescoço, está fazendo das tripas coração, dado que tem hoje três "saídas": a renúncia; a abertura de um processo de impeachment pelo Congresso, que continua a "comer no mesmo prato"; a do julgamento - provavelmente daqui a uma semana - pelo TSE, de processo que pede a cassação de Dilma e de Temer por possíveis descumprimentos da Lei Eleitoral ${ }^{35}$.

A menos que haja outra grande impunidade, o governo não chegaria ao fim (31/12/2018), e teríamos uma imediata eleição indireta (por esse Congresso!), certamente de alguém "contratado" especialmente para isso. Contudo, não seria nada fácil conduzir esse governo até o final. Se isso for possível, teremos eleições diretas em 2018 .

Existe uma questão maior nisso tudo. O PT já cumprira 13,5 de seus 16 anos de mandato, e a forte presença de Lula em pesquisas eleitorais e de opinião pública

(35) Poucos dias depois, o TSE julgou esse processo, vergonhosamente derrotado por $4 \times 3$, graças aos votos de dois ministros recentemente nomeados por Temer 
anteriores e recentes, parecia indicar sua vitória em 2018. Daí o impeachment, a forte campanha da Mídia, atitudes hostis por parte da população mais conservadora, além do comportamento da Justiça, para condenar Lula, tornando-o inelegível.

Mas o maior problema é que, nos demais partidos políticos e no PT, já eram raras outras lideranças de âmbito nacional para essa disputa. Por outro lado, tantas são as pessoas já condenadas por corrupção e outras mais, indiciadas, que "não sobrou ninguém". Assim, 2018 converteu-se em grande incógnita política: novo golpe? Indicação de um novo "salvador da pátria”? Parlamentarismo sem Lula?

Esta questão, já de si fundamental para a política, é também de enorme importância para uma radical e necessária mudança da política econômica, por si só muito complexa neste momento.

Mas é preciso lembrar ainda que a queda da taxa de inversão durante essa longa crise (desde 1980), acumulou uma enorme massa de investimentos em infraestrutura econômica e social, que não se realizaram, e que representam uma necessidade adicional de inversões, que são estimadas em cerca de $14 \%$ do PIB durante 20 anos! $!^{36}$

Acrescente-se também que, para a retomada do investimento privado, a determinação de alta elevação real da taxa de juros de longo prazo (TJLP) por uma nova (TLP) calculada na base da NTN-B de 5 anos, no BNDES, afugentará boa parte da demanda de financiamento para essa inversão. É mais uma medida pró cíclica, praticada em plena crise. Um anacronismo que inclusive fará encolher muito o atual porte do BNDES.

Então, também perguntamos: é possível ainda, para este país, ter um futuro promissor?

\section{Bibliografia citada}

BARROCAL, A. Na marra. Carta Capital, São Paulo, n. 950, p. 16-22, 3 maio 2017

BELluZZO, L. G. M.; TAVARES, M. C. Capital Financeiro e Empresa multinacional - o surgimento do capital financeiro. Revista Temas de Ciências Humanas, v. 9, 1980. Republicado em: Belluzzo, L. G. M. Antecedentes da tormenta. Unesp-Facamp, 2009.

BELLUZZO, L. G. M.; GALÍPOLO, G. Manda quem pode, obedece quem tem prejuízo. São Paulo: Contracorrente, 2017.

BLEANEY, M. The Rise and Fall of Keynesian Economics - an investigation of its contribution to capitalist development. London: Macmillan, 1985.

(36) Conforme valores estimados pela CGEE (2008). Para um resumo dessas estimativas, ver Cano (2010) 
CANO, W. Soberania e Política Econômica na América Latina. São Paulo / Campinas: Unesp/Unicamp. Instituto de Economia, 2000.

CANO, W. Crise de 1929, Soberania na Política Econômica e Industrialização 2006. In: CANO, W. Ensaios sobre a formação econômica regional do Brasil. Campinas: Ed. Unicamp, cap. 4, 1ª reimpressão 2006.

CANO, W. Uma Agenda Nacional para o Desenvolvimento. Revista Tempo no Mundo, Brasília, Ipea, v. 2, n. 2, dez. 2010.

CANO, W. (Des)Industrialização e (Sub)Desenvolvimento. Cadernos do Desenvolvimento, Rio de Janeiro, Centro Internacional Celso Furtado, n. 15, jul./dez. 2014.

CANO, W. Crise e Industrialização no Brasil entre 1929 e 1954: a reconstrução do Estado Nacional e a Política Nacional de Desenvolvimento. Revista de Economia Política, v. 35, n. 3, jul./set. 2015.

CARDOSO DE MELLO, J. M.; BELLUZZO, L.G.M. Reflexões sobre a crise atual. In: BELluZZO, L. G. M.; COUTINHO, R. (Org.). Desenvolvimento Capitalista no Brasil - ensaios sobre a crise. São Paulo, Editora Brasiliense, 1982. v. 1.

CGEE-Centro de Gestão e Estudos Estratégicos-MCT. Estudo da Dimensão Territorial para o Planejamento. Brasília, 2008. v. I, IV e V.

CHANG, H. J. Chutando a rscada: a estratégia do desenvolvimento em perspectiva histórica. São Paulo: Editora Unesp, 2004.

DAVIDOFF CRUZ, P. Notas sobre o endividamento externo brasileiro nos anos setentas. In: BELLUZZO, L. G. M.; COUTINHO, R. Desenvolvimento capitalista no Brasil: ensaios sobre a crise. São Paulo, Brasiliense, 1983. v. 2.

FAJNZYLBER, F. La industrialización trunca de America Latina. México: Nueva Imagen, 1983.

FAGNANI, E. O fim de um ciclo improvável (1988-2016). A política social dos governos petistas e a derrocada da cidadania pós-golpe. Campinas: UnicampInstituto de Economia, maio 2017. (Texto para Discussão, n. 300).

FANO, E. Crisi e ripresa economica nel bilancio del New Deal. In: TELÓ, M. (Coord.). Crisi e piano alternative degli anni trenta. Bari, Itália: DeDonato Edit, 1979. (Movimento, n. 58).

FURTADO, C. Formação econômica do Brasil. 5. ed. São Paulo: Fundo de Cultura, 1961.

FURTADO, C. A fantasia desfeita. 3. ed. São Paulo: Paz e Terra, 1989. 
FURTADO, C. Brasil: a construção interrompida. 2. ed. São Paulo: Paz e Terra, 1992.

GENTIL, D. L. Recessão econômica, privatização e desmantelamento da proteção social: a opção conservadora do governo Dilma Rousseff (2011-2015). In: SEMINÁRIO 50 ANOS UNICAMP, Campinas, 2015.

JINPING, Xi A Governança da China. Beijing: Editora de Línguas Extrangeiras, 2014.

KINDLEBERGER, C. La crisis económica 1929-1939. Barcelona: Ed. Critica, 1985.

LESSA, C. Quinze anos de política econômica. Campinas: Unicamp. IFCH, 1975. (Cadernos do Instituto de Filosofia e Ciências Humanas).

LESSA, C. A estratégia do desenvolvimento: sonho e fracasso. Campinas: Unicamp. Instituto de Economia, 1998.

LIMA, M. C. (Org.). Os boêmios cívicos: a assessoria econômico-política de Vargas (1951-1954). Rio de Janeiro: Centro Internacional Celso Furtado, 2013. (Pensamento Crítico).

MEDEIROS, C. A. A China como um duplo pólo na economia mundial e a recentralização da economia asiática. Rio de Janeiro: UFRJ-IE, maio 2005. Mimeografado.

NASSIF, A. A economia indiana no período 1950-2004: da estagnação ao crescimento acelerado. Lições para o Brasil? Rio de Janeiro: BNDES, 2006. (Textos para Discussão, n. 107).

OLIVEIRA, F. Augusto de. Economia política das finanças públicas no Brasil. São Paulo: Hucitec, 2009.

PAULINO, R. Socialismo no século XX: o que deu errado? São Paulo: Letras do Brasil, 2010.

SEERS, D. Inflación y crescimiento: resumen de la experiencia en América Latina. Boletin Económico de América, Santiago, Cepal, v. VII, n. 1, fev. 1962.

SGUISSARD, Campinas. Produtivismo e alienação acadêmica: fatores, vínculos e questões. In: SEMINÁRIO 50 ANOS UNICAMP, 2015.

SINGH, A. The Plan. The market and evolutionary economic reform in China. New York: Unctad, 1993. (Discussion Papers, n. 76).

TAVARES, M. C. Da substituição de importações ao capitalismo financeiro. Rio de Janeiro: Zahar, 1972. 
TAVARES, M. C. A retomada da hegemonia americana. In: TAVARES, M. C.; FIORI, J. L. (Org.). Poder e Dinheiro. Rio de Janeiro: Vozes, 1997.

TAVARES, M. C. Acumulação de capital e industrialização no Brasil. 3. ed. Campinas: Unicamp. Instituto de Economia, 1998.

TAVARES, M. C. Ciclo e crise: o movimento recente da industrialização brasileira. Campinas: Unicamp. Instituto de Economia, 1998.

TAVARES, M. C.; FIORI, J. L. (Org.). Poder e dinheiro. Rio de Janeiro: Vozes, 1997.

TAVARES, M.C.; MELIN, L.E. Pós-escrito 1997: A reafirmação da hegemonia americana. In: TAVARES, M. C.; FIORI, J. L. (Org.). Poder e Dinheiro. Rio de Janeiro: Vozes, 1997.

TEIXEIRA, A. O movimento da industrialização nas economias capitalistas centrais no pós-guerra. Rio de Janeiro: IEI/UFRJ, 1983. (Texto para Discussão, n. 25).

TOMAZELLI, I.; FERNANDES, A.; GADELHA, I. Fatura para aprovar Previdência chega a R 55 bilhões. O Estado de São Paulo, São Paulo, 21 maio 2017 , p. B5.

TORRES FILHO, E. T. O mito do sucesso: uma análise da economia japonesa no pós-guerra (1945-1973). Dissertação (Mestrado)-UERJ/IEI, Rio de Janeiro, nov. 1983. (Texto para Discussão, n. 37).

WOOD JR. T. Origens do produtivismo e o caminho do impacto social do conhecimento. In: SEMINÁRIO 50 ANOS UNICAMP, Campinas, 2015.

WORLD BANK. Economic growth in the 1990's: learning from a decade of reform. Washington, DC, 2005. 